International Journal of Life Sciences
Available online at www.sciencescholar.us
Vol. 6 No. 1, April 2022, pages: $10-18$
e-ISSN: 2550-6986, p-ISSN: $2550-6994$
https://doi.org/10.53730/ijls.v6n1.4739

\title{
Manufacture of Humus from Plant Residues
}

\author{
(1) Crossiark \\ Naina Lissette Ramon Amaya a , Lourdes Sthefania Aguirre Cobeña ${ }^{\text {b }}$, Titania Luviquenia Alava Gualpa c, \\ Anggie Daysi Flores Ochoa d, Cindy Brithany Freire Suarez e
}

Manuscript submitted: 18 Dec 2021, Manuscript revised: 09 Jan 2022, Accepted for publication: 27 Feb 2022

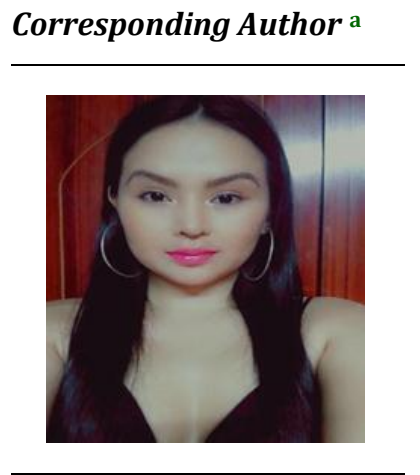

Keywords

domestic waste;

humus;

microorganisms;

soil;

sustainability;

\begin{abstract}
Humus is a substance that is created from the decomposition of plant residues with the help of beneficial microorganisms (fungi and bacteria) present in the surface layer of soil, with a massive amorphous consistency, homogeneous and dark in color due to a large amount of carbon it contains, and which is essential to sustain the total soil ecosystem since it helps maintain available nutrients for the plants. The objectives achieved are the elaboration of organic humus from vegetable residues within the homes, to generate a product that contributes to the improvement of the soil, through the methodology of the surveys, favorable results were obtained for the realization of the organic humus, in the same way, it concludes that by elaborating organic humus, the plants have better growth and therefore it is an aid to the environment since through this technique we can reduce and apply the use of vegetable residues, which will become organic matter and reach to reduce pollution in all homes, contribute to the soil and restore the proper nutrients to obtain adequate fertilization without the increase of chemicals harmful to humans.
\end{abstract}

International Journal of Life Sciences (C) 2022.

This is an open access article under the CC BY-NC-ND license (https://creativecommons.org/licenses/by-nc-nd/4.0/).

\section{Contents}

Abstract

1 Introduction

2 Materials and Methods

3 Results and Discussions

4 Conclusion

a Escuela Superior Politécnica de Chimborazo, Orellana, Ecuador

b Escuela Superior Politécnica de Chimborazo, Orellana, Ecuador

c Escuela Superior Politécnica de Chimborazo, Orellana, Ecuador

d Escuela Superior Politécnica de Chimborazo, Orellana, Ecuador

e Escuela Superior Politécnica de Chimborazo, Orellana, Ecuador 


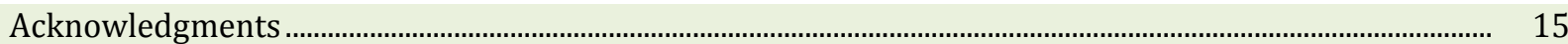

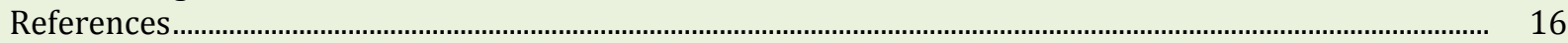

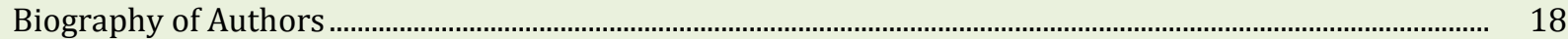

\section{Introduction}

The earthworm humus is an organic fertilizer is considered the best fertilizer in the world, widely used in bean cultivation (Pupiro, 2013). the interest of farmers to promote vermiculture, due to the role played by worms in the transformation of polluting organic waste into worm humus, according to farmers it is an irreplaceable fertilizer for soil improvement and plant nutrition such as benefit in agriculture (Ochoa Piñuela, 2009). Humus is a decomposition of vegetable residues oriented to the use of waste in the use of vegetables that we consume daily at home, which provides us with organic matter and thus we can obtain humus based on vegetable residues, as well as humus beyond being profitable is a way of life and an awareness of the current problems of the world (Tenecela, 2012). This product can be obtained in family gardens (HueteOrtega et al., 2011).

Humus is used in many places for the intensive cultivation of many products, in Mexico it is applied in the intensive cultivation of chili, with very good results (Nieto-Garibay et al., 2002). Ecological issues and the importance of Recycling of vegetable waste is today a task that is carried out very often (Orozco Corral et al., 2016). This is how in this project the humus of vegetable waste is presented as a means of sustainable development that More than being economically profitable, it is necessary for the good maintenance of agricultural soils. Humus constitutes an important reserve of organic matter in the soil, therefore it is useful for the farmer because it improves the physical properties of the soil by giving it a better structure (Evelin, 2018).

Many tests have been carried out to produce humus from organic materials and waste in Chimborazo, the effect of using sawdust was evaluated combined with bovine manure as feed to produce eisenia foetida worm humus (Californian red worm) (Cajas, 2009). This project is oriented to the elaboration of humus from the vegetable residues inside the homes, to generate a product that contributes to the improvement of the soil, which consists of recycling all types of vegetable residues and converting them into natural fertilizers through the natural decomposition by microorganisms, is of paramount importance as it contributes to a wellstructured soil that produces high-quality plants. Humus is essential to sustain the total soil ecosystem. Improvements to the physical structure of the soil facilitate tillage, increase the capacity to store water, reduce erosion, improve the formation and harvesting of tuber crops, and produce deeper and more prolific root systems in plants (Diya'uddeen et al., 2012; Domingo \& Nadal, 2009).

\section{Materials and Methods}

This research was carried out in the province of Orellana, city of Coca, Santa Rosa neighborhood. For the preparation of humus, different materials were used, such as a plastic tray, to mix the waste, In addition to vegetable waste, eggshells, strawberries, herbs, cucumbers, onions, oranges, peppers, lemons, ripe peels, sawdust, carrots, soil, potatoes and dry leaves. The raw material to produce humus was placed in a plastic container with a fine layer of soil of 500 grams, then 2 pounds of waste collected from 4 days was added, a fine layer of sawdust was placed, placing 2 more pounds of plant residues collected from 4 days adding dry leaves to it was added again half a pound over 4 days, again adding another thin layer of soil and finally adding 250 grams of water. To evaluate the results, a survey was carried out on 63 people from the Polytechnic High School of Chimborazo, Orellana campus, the population surveyed was towards the teachers and students of the Agronomy career (Beltrán Brito, 2016).

Amaya, N. L. R., Cobeña, L. S. A., Gualpa, T. L. A., Ochoa, A. D. F., \& Suarez, C. B. F. (2022). Manufacture of humus from plant residues. International Journal of Life Sciences, 6(1), 10-18. https://doi.org/10.53730/ijls.v6n1.4739 


\section{Results and Discussions}

According to the investigation carried out, an integrated family of four people, which is the average habitat in Francisco de Orellana, generates 6 pounds of garbage every day, 98\% of which ends up in the landfill, even though, according to the Municipality, $57 \%$ of the waste generated by a family is organic. The project could encompass self-sustaining production in each house in the canton, managing to establish agrarian and selfsustaining sovereignty for the family economy. The main residues that are produced the most in a family are vegetable residues such as onion, tomato, potato, ripe, vegetable peels and others (Piccolo, 1996; Nannipieri et al., 1996).

\section{Humus production}

Throughout the development of this project, the results obtained are satisfactory, offering knowledge and experiences that guide the studies and development of an environmental culture, the proper management of plant residues, these aspects generate a change of attitude towards the problem environment on the management and use of plant residues. One of the aspects learned was the decomposition process with a time of 2 months and 19 days, obtaining as a final product an odor like earth and a blackish color. To dry the product, it was laid out under protected conditions at room temperature with a drying time of 5 days, with 30\% humidity and thus being ready for packing (Crespi, 2001; Byrom, 1987).

The production of humus is a sustainable activity that, while generating income, complies with the ecological and social aspects. The use of plant residues helps the soil sustainability process, saving on fertilizers so there is no need to buy fertilizers or substrates, since it can be produced at home for free and of great quality, in this sense it is estimated that between 40 to $50 \%$ of a domestic garbage bag is made up of vegetable waste, which can be transformed into a rich compost in homes. This process helps reduce pollution, in addition to fuel consumption for transportation, there will be less accumulation of waste in landfills and there is a notable reduction in toxic substances and harmful gases in them. In landfills, organic remains rot, wrapped with all kinds of inorganic materials that are burned, with the production of humus emissions into the atmosphere will be avoided, reducing the greenhouse effect (Soane \& Van Ouwerkerk, 1995; Bosatta \& Ågren, 1999).

The humus obtained from plant residues can be used to improve and strengthen the soil, with an assimilation quality incomparably superior to that of chemical substances or substrates of unknown origin, with the humus the soil is invigorated and favors the activity of microbial life, avoiding erosion, the leaching of nutrients, enhances and favors all the biological activity of the soil, which is the best guarantee to prevent pests and diseases in plants, it is important to remember that adding materials with different properties was essential to reach to achieve a good result in the humus (Mandado \& Bravo, 2014). The mixture of soil with humus results in 'strong and vigorous plants that are resistant to pests and diseases, they are easy to absorb food; In addition to having fewer pest and disease attacks, Figure 1 shows the smoke obtained and the plants that have been cultivated.
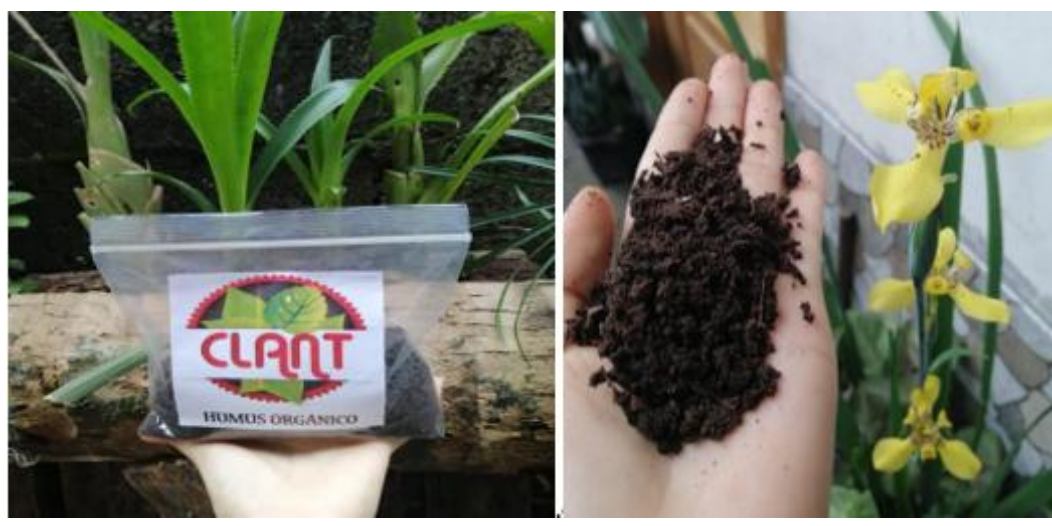

Figure 1. Produced humus and some plants that have been deposited with fertilizers 
As can be seen, organic fumes are found in the product evaluation process, the result was that it maintained moisture in the plant residues, on day 7 of the experiment I observed the presence of worms in the waste and a bad smell, by day 10 the soil has a dark color, by day 15 the vegetables are in the process of decomposition, on day 25 microorganisms (fungi) with a life time of 2 days, observing at 51 the blackish material and the shell of the eggs are observed, these materials achieved their total decomposition with an odor similar to earth at approximately 80 days (Pope et al., 2004; Costanza \& Patten, 1995).

\section{Interest of the city of Orellana in humus}

The students and teachers of the agronomy career through the surveys showed interest in obtaining fumes with vegetable residues, they were asked which would be the best place to produce humus, showing the results in figure 2 .

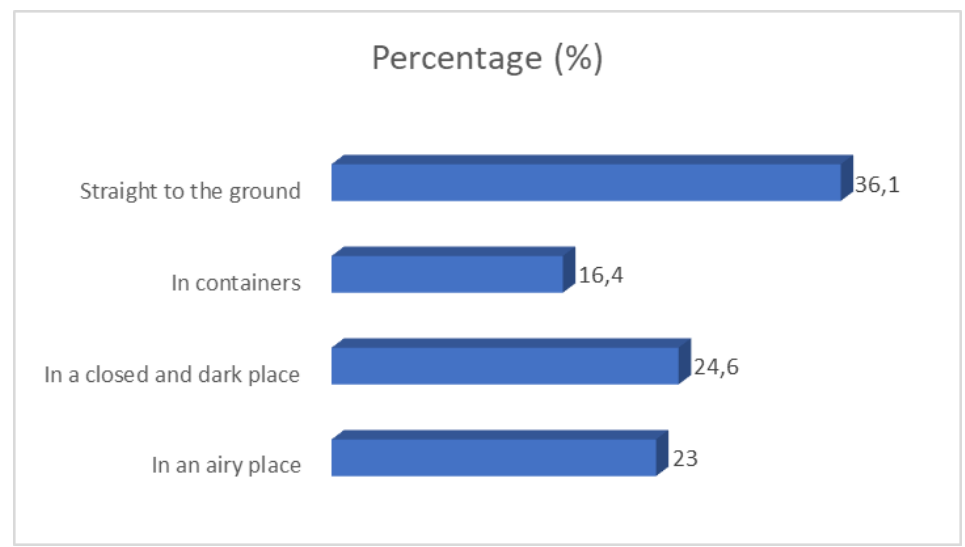

Figure 2. Suitable sites to produce humus

As shown in the figure, most respondents agree that the best suitable site would be directly on the ground, $24.6 \%$ responded that they prefer a closed and dark place, few agreed that it be carried out in a container. The amount of waste generated daily in homes was also consulted, the results are shown in figure 3.

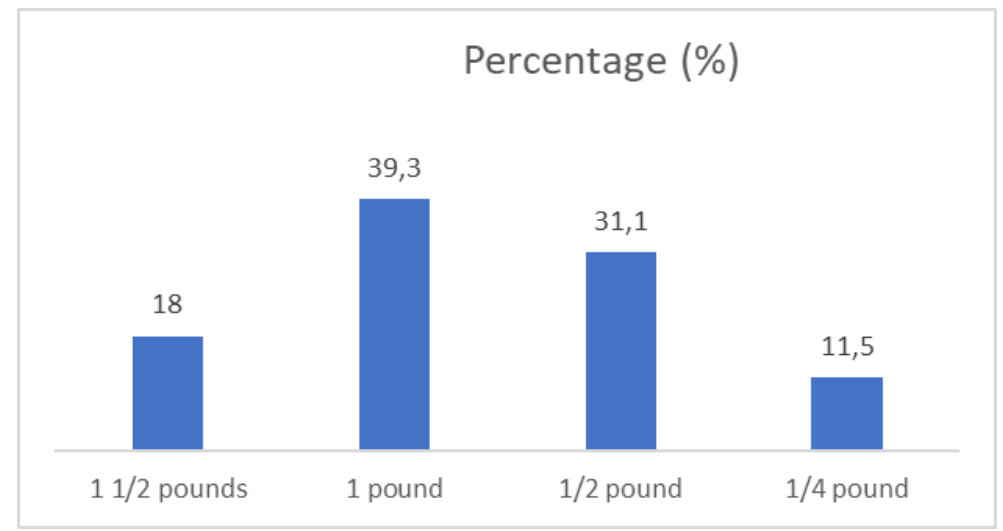

Figure 3. Amount of residual generated

As can be seen, $39.3 \%$ of the respondents generate 1 pound of vegetable waste, being the highest percentage $31 \%$ generate $1 / 2$ pound, those that generate the least are around $1 / 4$ pound. It was consulted related to the products that should not be added in the preparation of humus, the results are shown in figure 4.

\footnotetext{
Amaya, N. L. R., Cobeña, L. S. A., Gualpa, T. L. A., Ochoa, A. D. F., \& Suarez, C. B. F. (2022). Manufacture of humus from plant residues. International Journal of Life Sciences, 6(1), 10-18. https://doi.org/10.53730/ijls.v6n1.4739
} 


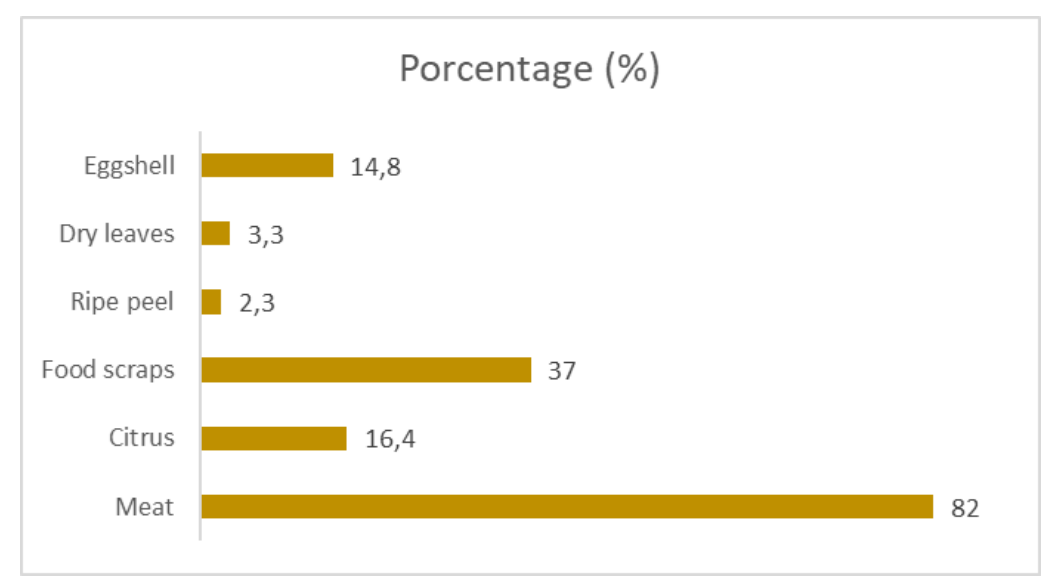

Figure 4. Products that should not be added in the preparation of humus

As can be seen, the largest number of people responded that leftover meat should not be added, followed by a considerable percentage who state that leftovers of spicy foods should not be added, it is worth noting how few people responded that eggshells and eggshells should not be added. It was relevant that when consulting related to the importance of preparing humus, $82 \%$ of the respondents answered affirmatively, this analysis allows corroborating that the population surveyed is clear about the importance of using ecological fertilizers, in addition to being a simple way to reduce and obtain an excellent quality fertilizer, just as the quality of garbage bags sent to landfills would be reduced (Thyagaraju, 2016; Archana et al., 2016).

Through the surveys given to 63 people, the results that we will take into account in the 11 questions, we could implement our product called CLANT since there are people who are accepted and know about the benefits as well as the help it provides to our organism in the same way to the environment since this could not generate contaminants, to the soil and our crops since everything would be formed and treated through a cycle of decomposition of our vegetables and thus would become organic humus, we would have a high acceptance of our product in terms of its sales since by knowing and experimenting we could have a very good quality product. In the research process it was noted that not all people have knowledge about the preparation of humus, or how to treat their waste from home to be friendly to the environment. Humus is characterized by its blackish color, mainly due to the large amount of carbon it contains. It is mainly found in the upper parts of soils with organic activity, it also adapts to any type of crop.

The main advantage observed is that it increases the quality of the plant and its fruit, by conserving soil moisture, causing the leaves to remain green. The organic matter that decomposes and produces humus is basically made up of plant fragments such as leaves, stems, roots, bark, seeds, and pollen in the decomposition phase. Also due to root exudates and excrement from some animals such as earthworms and other microbial soil animals, without forgetting the contribution made by dead animals and many other microorganisms, such as fungi and bacteria. Humus constitutes an important reserve of organic matter in the soil and its influence on it is both physical, chemical and biological.

Physical as it gives consistency to both light and compact soils, prevents the formation of crusts, helps retain water and drain chemicals as it helps regulate plant nutrition, improves ion exchange and assimilation of mineral fertilizers, it provides nitrogenous products to the degraded and biological soil because it serves as support and food for microorganisms (Álvarez et al., 2015). Vermiculture is understood as a series of operations related to the breeding and production of worms (formers of humus), Access Agriculture (2019), through them (through biological oxidation processes), of organic biological waste for recycling in the form of fertilizer called earthworm humus, to be able to obtain earthworm humus will depend on the management provided once the planned dimension is reached, each crib will almost always be with its complete harvest population, from 3 to 4 months the humus is extracted (Albán et al., 2002). To obtain humus from plant residues, it took a decomposition time of 2 months and 19 days. 


\section{Conclusion}

Humus has the function of returning to the earth its natural nutrients, essential for production to be effective and efficient, in addition to collaborating in reversing the current ecological imbalance by returning to nature what has been given, what is dead becomes life and it returns to die and recreate life, that is, a beneficial cycle for all living beings (plants, animals and human beings). By making use of organic waste in an orderly manner, the organic matter transformation mechanism inhibits the release of polluting products from the soil, water, and air, which are generated by the decomposition of said matter. The humus made from the plant residues took 80 days to break down into a loose-textured, odorless black material. Eggshells were the only residues that did not reach mineralization. The organic waste produced by an average family in the city of Francisco de Orellana is mainly composed of the skins of onions, tomatoes, potatoes, ripe vegetables. The average production is 6 pounds per day.

\section{Acknowledgments}

We are grateful to two anonymous reviewers for their valuable comments on the earlier version of this paper.

Amaya, N. L. R., Cobeña, L. S. A., Gualpa, T. L. A., Ochoa, A. D. F., \& Suarez, C. B. F. (2022). Manufacture of humus from plant residues. International Journal of Life Sciences, 6(1), 10-18. 


\section{References}

Access Agriculture. (2019). Earthworm humus.

Albán Donoso, A., Marín Ronquillo, V., \& Vás2 Aguirre (2002). Microenterprise project for the production of earthworm humus in the province of Guayas.

Álvarez, M., Eguiarte, D., Llamas, J., Velasco, J., \& Plascencia, J. (2015). Caracterización fisicoquímica y bacteriológica de lixiviados provenientes de granja lombrícola en tlajomulco.

Archana, .-., Datta, C., \& Tiwari, P. (2016). Impact of environmental degradation on human health. International Research Journal of Management, IT and Social Sciences, 3(1), 1-6. Retrieved from https://sloap.org/journals/index.php/irjmis/article/view/341

Beltrán Brito, J. A. (2016). Humus líquido más abono bovino en la producción primaria forrajera de la Brachiaria decumbes (Pasto dallis) (Bachelor's thesis, Escuela Superior Politécnica de Chimborazo).

Bosatta, E., \& Ågren, G. I. (1999). Soil organic matter quality interpreted thermodynamically. Soil Biology and Biochemistry, 31(13), 1889-1891. https://doi.org/10.1016/S0038-0717(99)00105-4

Byrom, D. (1987). Polymer synthesis by microorganisms: technology and economics. Trends in biotechnology, 5(9), 246-250. https://doi.org/10.1016/0167-7799(87)90100-4

Cajas, F. (2009). El conocimiento de ingeniería como conocimiento escolar.

Costanza, R., \& Patten, B. C. (1995). Defining and predicting sustainability. Ecological economics, 15(3), $193-$ 196. https://doi.org/10.1016/0921-8009(95)00048-8

Crespi, B. J. (2001). The evolution of social behavior in microorganisms. Trends in ecology \& evolution, 16(4), 178-183. https://doi.org/10.1016/S0169-5347(01)02115-2

Diya'uddeen, B. H., Aziz, A. A., Daud, W. M. A. W., \& Chakrabarti, M. H. (2012). Performance evaluation of biodiesel from used domestic waste oils: a review. Process Safety and Environmental Protection, 90(3), 164179. https://doi.org/10.1016/j.psep.2012.02.005

Domingo, J. L., \& Nadal, M. (2009). Domestic waste composting facilities: a review of human health risks. Environment international, 35(2), 382-389. https://doi.org/10.1016/j.envint.2008.07.004

Evelin, J. (2018). 57\% of garbage can be reused because it is organic.

Huete-Ortega, M., Calvo-Díaz, A., Graña, R., Mouriño-Carballido, B., \& Marañón, E. (2011). Effect of environmental forcing on the biomass, production and growth rate of size-fractionated phytoplankton in the central Atlantic Ocean. Journal of Marine Systems, 88(2), 203-213.

Mandado, L. J. L., \& Bravo, Y. L. P. (2014). Effect of worm humus leachate on morphological indicators in the cultivation of onion (Allium cepa L.). Centro Agrícola.

Nannipieri, P., Sequi, P., \& Fusi, P. (1996). Humus and enzyme activity. In Humic substances in terrestrial ecosystems (pp. 293-328). Elsevier Science BV. https://doi.org/10.1016/B978-044481516-3/50008-6

Nieto-Garibay, A., Murillo-Amador, B., Troyo-Dieguez, E., Larrinaga-Mayoral, J. A., \& Garcia-Hernandez, J. L. (2002). The use of compost as an ecological alternative for sustainable production of hot pepper (Capsicum annuum L.) in arid zones. Interciencia, 27(8), 417-421.

Ochoa Piñuela, J. I. (2009). Beneficios que ofrece el humus de lombriz a los cultivos de manzana. Extraído $e l, 21$.

Orozco Corral, A. L., Valverde Flores, M. I., Martínez Téllez, R., Chávez Bustillos, C., \& Benavides Hernández, R. (2016). Physical, chemical and biological soil properties with biofertilization in apple orchards. Terra Latinoamericana, 34(4), 441-456.

Piccolo, A. (1996). Humus and soil conservation. Humic substances in terrestrial ecosystems, 225-264. https://doi.org/10.1016/B978-044481516-3/50006-2

Pope, J., Annandale, D., \& Morrison-Saunders, A. (2004). Conceptualising sustainability assessment. Environmental impact assessment review, 24(6), 595-616. https://doi.org/10.1016/j.eiar.2004.03.001

Pupiro, L. A. (2013). Efecto del humus de lombriz en el rendimiento y las principales plagas insectiles en el cultivo del frijol (Phaseolus vulgaris L.). Cultivos Tropicales, 25(1), 89-95.

Soane, B. D., \& Van Ouwerkerk, C. (1995). Implications of soil compaction in crop production for the quality of the environment. Soil and Tillage Research, 35(1-2), 5-22. https://doi.org/10.1016/0167-1987(95)004758

Tenecela, X. (2012). Producción de humus de lombriz mediante el aprovechamiento y manejo de los residuos orgánicos. Ecuador, Universidad de Cuenca. 
Thyagaraju, N. (2016). Water pollution and its impact on environment of society. International Research Journal of Management, IT and Social Sciences, 3(5), 1-7. Retrieved from https://sloap.org/journals/index.php/irjmis/article/view/360

Amaya, N. L. R., Cobeña, L. S. A., Gualpa, T. L. A., Ochoa, A. D. F., \& Suarez, C. B. F. (2022). Manufacture of humus from plant residues. International Journal of Life Sciences, 6(1), 10-18. https://doi.org/10.53730/ijls.v6n1.4739 


\section{Biography of Authors}

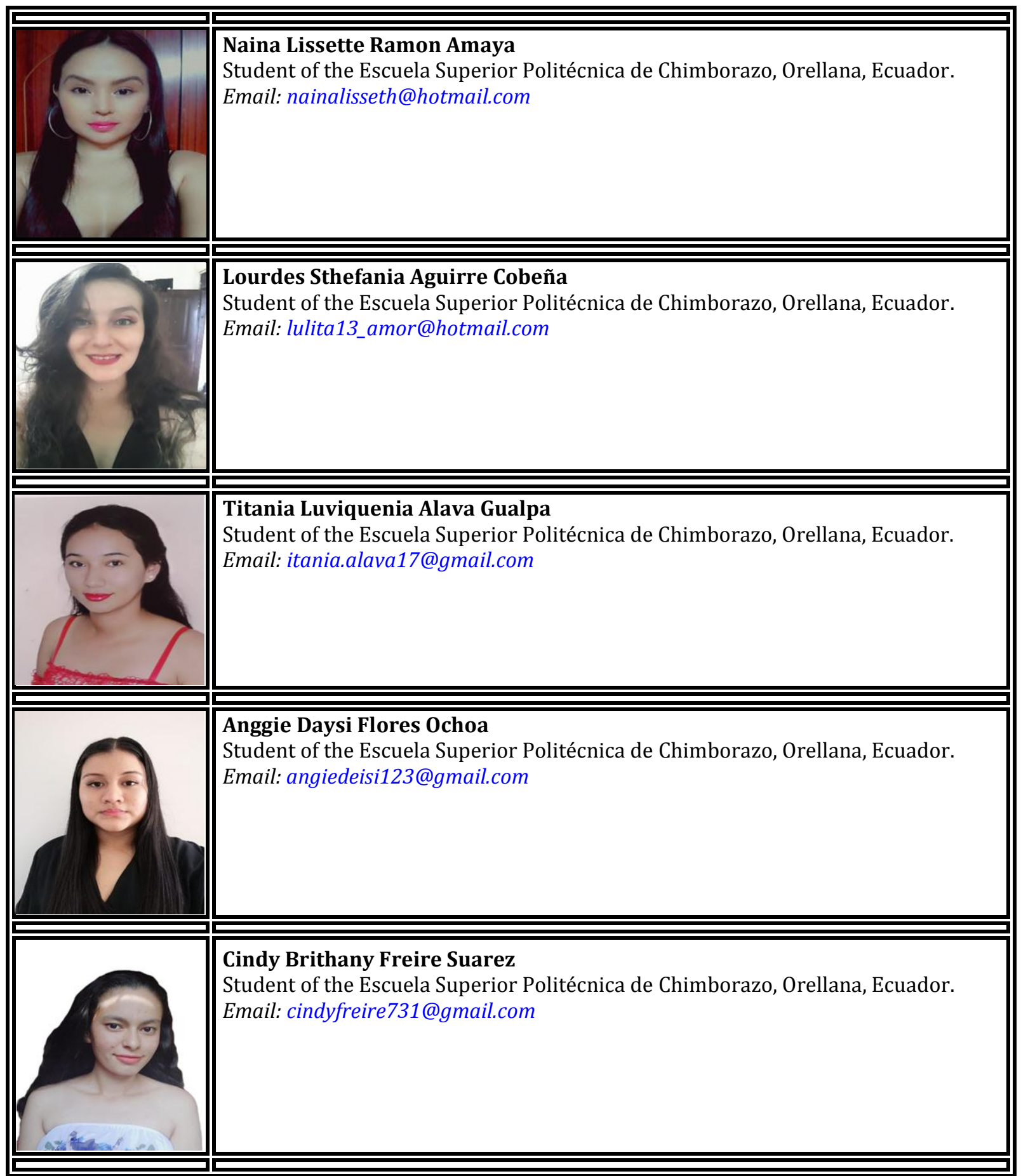

